\title{
Water Quality Index of southern part of the Kathmandu Valley, Central Nepal; evaluation of physical water quality parameters of shallow wells
}

\author{
*Bimal Bohara \\ Central Department of Geology, Tribhuvan University, Kathmandu, Nepal
}

\begin{abstract}
Physical water quality of shallow groundwater of the southern part of the Kathmandu Valley was studied and analysed. Being the capital city of the country, the population is increasing day by dayand consequently the demand of water supply has also increased. Analyses reveal ranges of temperature to be $15.3-24.2^{\circ} \mathrm{C}, \mathrm{pH}$ to be $5.67-8.07$, electrical conductivity to be (EC) $230-2860 \mu \mathrm{S} / \mathrm{cm}$, and dissolved oxygen (DO) to be $0.09-9.1 \mathrm{mg} / \mathrm{L}$ in dry season whereas in wet season temperature, $\mathrm{pH}$, EC and DO ranges are respectively $19.6-27.3^{\circ} \mathrm{C}, 5.92-8.3,183-3030 \mu \mathrm{S} / \mathrm{cm}$ and $0.19-7.9 \mathrm{mg} / \mathrm{L}$. Water Quality Index (WQI) map shows that the upstream river areas contain good water quality than the downstream areas. The areas like Kalanki and Satdobato have poor water quality according to the guidelines of Nepal Drinking Water Quality Standard.
\end{abstract}

Key words: Shallow well, Southern Kathmandu, EC, DO, Water Quality Index

Received: 2 Aug, 2016

Accepted: 25 Aug, 2016

\section{INTRODUCTION}

The Kathmandu Valley is a bowl shaped, intermontane basin formed in the Lesser Himalayan Midland Zone of the Central Nepal. People of the Kathmandu Valley have been dependent on groundwater sources like dug well, spouts and spring from the ancient time. The demand of groundwater is highly increasing in the valley, due to the uncontrolled population growth and unplanned urbanization. Groundwater, which is water that exists underground (Groundwater Foundation, 2012), and groundwater resources within the Kathmandu basin play the major role for fulfilling the partial demand of water supply. Among groundwater resources, shallow wells are considered as the major source for fulfilling the water demand for domestic purpose (drinking, cooking,

\footnotetext{
*Corresponding author:

E-mail address: boharabimal77@gmail.com
}

washing, irrigation, farming, etc.). Shallow wells, which are driven generally less than the depth of $15 \mathrm{~m}$, are constructed by digging, boring, driving and jetting. As being near to the surface, human activities may consequently pollute this water source over a time and make it unsafe for using without prior treatment. More so, several research findings (UNICEF, 2008; WHO, 2010) have revealed a definite correlation between human socio-economic and industrialization activities to pollution patterns/trends of groundwater. Contamination well can lead to the spread of various water-born diseases. The quality of drinking water is a powerful environmental determinant of health (WHO, 2010).

This study will be another approach for study of hydrogeological condition of the Kathmandu Valley in shallow wells. Precipitation and infiltration are the main recharge agents for the groundwater source. The water 
quality is under intense stress from increasing demand and withdrawal, significant changes in land use pattern, climate change and pollution arising from geological and geochemical environment (Edmunds and Smedley 1996).

The natural groundwater quality isn't always good. The natural quality can vary from one rock type to another and also within aquifers along groundwater flow paths (MacDonald and Calow, 2009). The Kathmandu Valley sediments have been divided into eight different stratigraphic units. (Yoshida and Igarashi, 1984; Yoshida and Gautam, 1988). The oldest is the Lukundol Formation, followed by intermediate gravel deposits such as Chapagaon, Boregaon and Pyanggaon Deposits developed in the course of tilting of the lake due to activation of the Main Boundary Thrust (MBT) towards the southern margin (Sakai, 2001). The younger sediments are in the northern part as the Gokarna Formation, Thimi Formation, Patan Formation and the Recent terrace deposits (Yoshida and Igarashi, 1984). The sediment deposited in different formations directly influences infiltration of water to shallow wells. Gravel and sand are considered as good aquifer with high potential zone for groundwater whereas clay, silt and hard rock as low potential water zone, although water has been extracted from low permeable layers of the Kalimati Formation for domestic purpose in the Kathmandu Valley.

The major river flowing through the southern part of the Kathmandu Valley is the Bagmati Rivdr, Kodku Khola, Nakhu Khola, Godavari Khola, Balkhu Khola, Bosan Khola and the Hanumante Khola. The recharge and discharge interchange within shallow groundwater and drainage according to climate and fluctuation of water table.

Studies on groundwater have been carried out in different parts of the southern Kathmandu; however, no comprehensive study has been conducted on the shallow groundwater quality in the study area. In this study, temperature, $\mathrm{pH}, \mathrm{EC}$ and dissolved oxygen (physical parameters of water quality) of shallow well waters were determined.

\section{MATERIALS AND METHODS}

The Kathmandu Valley extends for about $30 \mathrm{~km} \mathrm{E-}$
$\mathrm{W}$ and $25 \mathrm{~km} \mathrm{~N}-\mathrm{S}$ covering the area of $656 \mathrm{sq} \mathrm{km}$. The study area that focuses mainly the southern Kathmandu, is located between latitude $27^{\circ} 32^{\prime} 34^{\prime \prime}$ to $27^{\circ} 49^{\prime} 11^{\prime \prime} \mathrm{N}$ and longitude $85^{\circ} 11^{\prime} 10^{\prime \prime}$ to $85^{\circ} 31^{\prime} 10 \mathrm{E}$. The study area covers Balambu and the Bagmati River at the north, Chapagaun at the south, Bosan area at the west and Bhaktapur at the east (Fig. 1).

\section{Water quality data collection}

Geologically the area lies on the Kathmandu Nappe in the Lesser Himalaya Zone, south of the Great Himalaya Range separated by deep valleys of the Likhu Khola and the Shindu Khola (600 to $1300 \mathrm{~m}$ above sea level) (Sakai, 2001). The basin was originated tectonically (Hagen, 1969). Sakai (2001) defined the basin as a piggyback basin lying between the pop-up mountains of the Mahabharat Lekh to the south and the Shivapuri Lekh to the north. Drainage pattern of the Kathmandu Valley is governed by a centripetal drainage system. The area is a subtropical zone which has a mild climate most of the year. The annual mean temperature of the valley is $18.3{ }^{\circ} \mathrm{C}$. During the rainy monsoon season between June and August, 70 to $80 \%$ of the total annual precipitation occurs by winds from Bay of Bengal.

Altogether 440 data were collected during both seasons, of which 220 wells water data were collected in dry season and the next 220 data from same wells were collected in rainy season. Data were collected from only shallow dug wells less than $15 \mathrm{~m}$.

Wells in the study area were located in the topographic map from the field study. Longitude, latitude and elevation of each of the wells were taken by GPS (Garmin Colorado 300). Physical water quality parameters like DO, EC, $\mathrm{pH}$ and temperature were measured in the field because they showed the unstable behavior with change in surrounding environment. Scientific instruments were used in the field for the purpose of data acquisition like DO Meter (Mettler Toledo SG3-ELK) and EC-pH Meter (Mettler Toledo SG23-SevenGo; DuoTM pH/Conductivity meter). Water Depth Logger was used to measure the water table depth from the ground surface. Various other information like its age, depth, structure and surrounding condition of each well were also noted. 


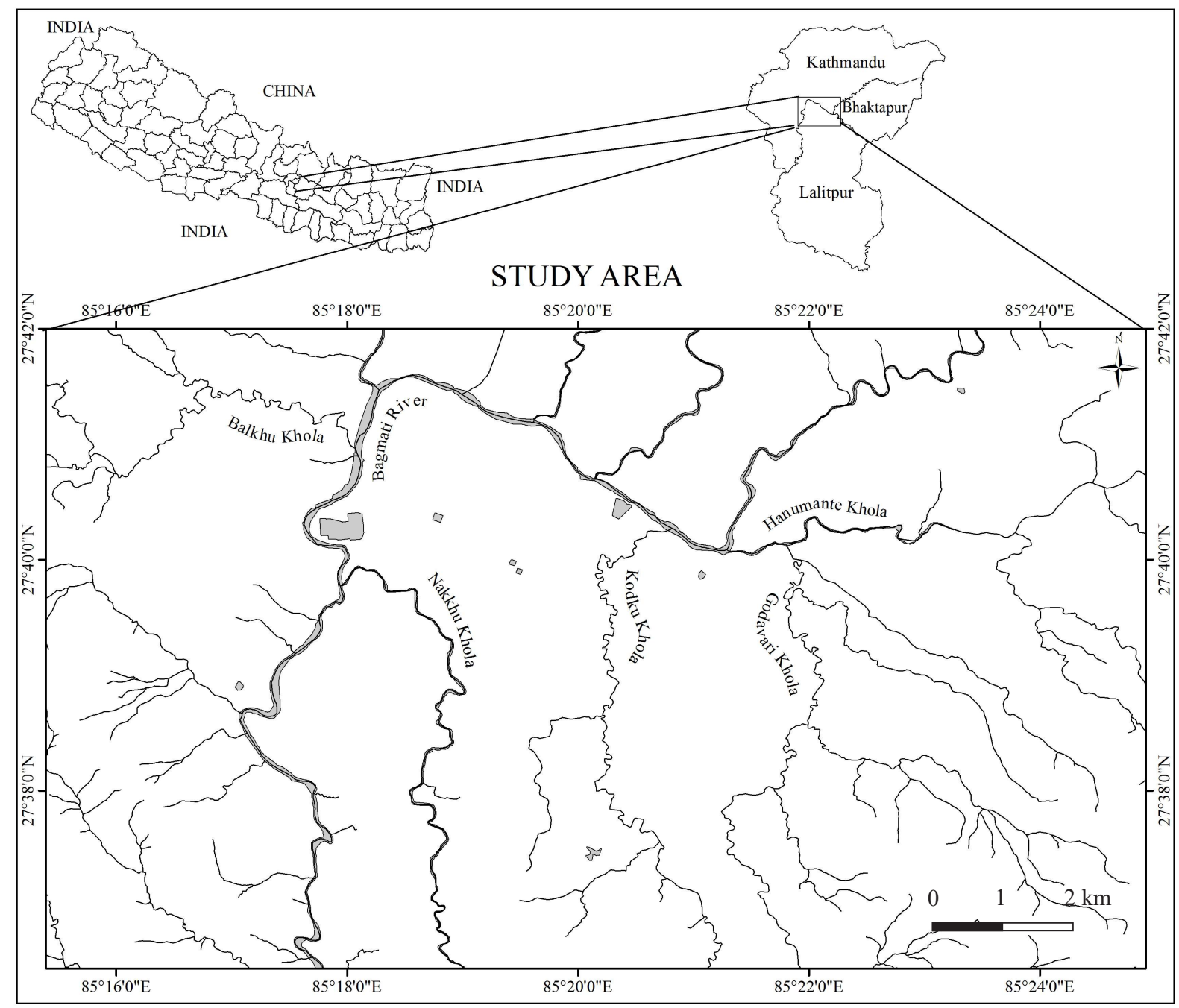

Fig. 1: Location map of study area

\section{Water Quality Index (WQI) map based on physical parameters}

Based on different physical water quality parameter measured in study area, a WQI was calculated and a map was prepared. An index is a mean device to reduce a large quantity of data down to the simplest form. It is defined as a technique of rating that provides the composite influence of individual water quality parameter on overall quality of water of that area (Gupta et al., 2015).

Following four steps were followed for calculation of WQI:

\section{i. Assigning weight (w)}

In this step the weights for individual parameter were assigned on the scale of 4 to 1 based on their contribution for water quality. For the most important scale of 4 was assigned and for the least important, the scale of 1 was assigned in this study.

ii. Relative weight (W)

Relative weight of each parameter was calculated using the following equation: 


$$
\mathrm{W}=\frac{\mathrm{W}}{\sum_{\mathrm{i}=1}^{\mathrm{n}} \mathrm{W}}
$$

Where, $\mathrm{w}$ is weight of each parameter and $\mathrm{n}$ is number of parameters.

\section{iii. Quality Rating Scale (q)}

The quality rating scale $\mathrm{q}$ for each parameter was determined by dividing the concentration of each parameter to its respective permissible standards and multiplied by 100

$$
q=\frac{c}{s} \cdot 100
$$

Where, $\mathrm{c}$ is concentration of each measured parameter and $\mathrm{s}$ is the maximum allowable level for that parameter.

\section{iv. Sub Index and WQI}

To determine the sub index (SI) and WQI, the following equations were used.

$$
\begin{gathered}
\text { Sub Index }(\mathrm{SI})=\mathrm{q} \times \mathrm{W} \\
\mathrm{WQI}=\sum_{\mathrm{i}=1}^{\mathrm{n}} \mathrm{SI}
\end{gathered}
$$

Where, SI is sub index of each parameter, q is quality rating scale of each parameter and $n$ is number of parameter. Thus, obtained WQI value was described with their respective description value (Table 1).

\section{RESULTS AND DISCUSSIONS}

Electrical conductivity (EC) measures the dissolved ionic component in water and hence electrical characteristic. Value ranged from $230-2860 \mu \mathrm{S} / \mathrm{cm}$ with average of $807.66 \mu \mathrm{S} / \mathrm{cm}$ in dry season and $183-3030$ $\mu \mathrm{S} / \mathrm{cm}$ with average of $765 \mu \mathrm{S} / \mathrm{cm}$ in wet season (Annex Table 1). The water with EC of $<1500 \mu \mathrm{S} / \mathrm{cm}$ is considered as potable according to NDWQS (2005). Kalanki and some part of Satdobato in both seasons have values greater than $1500 \mu \mathrm{S} / \mathrm{cm}$. It can be due to pollution of water. The trend of value of EC in shallow ground water is increasing from the south to the north of the study area. As EC gives an indication of amount of total dissolved substitution in water (Yilmaz and Koc, 2014), high EC can be considered as having more solubility of minerals and other materials.

A pH ranges were 5.67-8.07 in dry season and 5.92-8.3 in wet season (Annex Table 1). Some wells in the Nakhu Khola catchment and the Central Zoo Area had acidic $\mathrm{pH}$ value less than 6.5 , falling slightly below the guideline limit of 6.5-8.5, thus indicating corrosiveness. However, an average $\mathrm{pH}$ of 7.07 in dry season and 7.26 in wet season is recorded. The World Health Organization (WHO, 2010) recommends a pH value of 6.5 or higher for drinking water to prevent corrosion. A pH above 8.0 would be disadvantageous in

\begin{tabular}{|c|c|c|c|}
\hline Parameter & Weight (w) & Relative weight (W) & Allowable Standards \\
\hline$\overline{\mathrm{EC}}$ & 4 & 0.4 & $1500 \mu \mathrm{S} / \mathrm{cm}$ (a) \\
\hline $\mathrm{pH}$ & 3 & 0.3 & $6.5-8.5$ (a) \\
\hline DO & 2 & 0.2 & $3-8 \mathrm{mg} / \mathrm{L}(\mathrm{b})$ \\
\hline Temperature & 1 & 0.1 & $20-25^{0} \mathrm{C}(\mathrm{c})$ \\
\hline Total & 14 & 1 & \\
\hline
\end{tabular}
the treatment and disinfection of drinking water with chlorine (UNICEF, 2008). However, $\mathrm{pH}$ values between

Table 1: Relative weight for physical water quality parameter and standards

Table 2: Water Quality Index Legend

\begin{tabular}{ll}
\hline WQI Value & Description \\
\hline$>100$ & Poor \\
$75-100$ & Average \\
$<75$ & Good \\
\hline
\end{tabular}


6.5 and 8.5 usually indicate good water quality and this range is typical of most drainage basins of the world (UNEP/GEMS, 2007). The reason for change could be chemical used and pollution in agriculture runoff (EPA, 2012).

The DO ranges from 0.09 to $9.1 \mathrm{mg} / \mathrm{L}$ in dry season. In wet season it ranges from 0.19 to $7.9 \mathrm{mg} / \mathrm{L}$ (Annex Table 1). Areas like Katunje, Balkot, Lubu, Thaiba, Sunakothi and Kalanki had low DO often less than 2 $\mathrm{mg} / \mathrm{L}$. Except some few wells of Chobhar, Gwarko and Godavari where DO values range greater than 4 , in almost all remaining wells, DO ranges from 2 to $4 \mathrm{mg} / \mathrm{L}$ in wet season. In dry season, DO of well water ranges from 0.09 to $2 \mathrm{mg} / \mathrm{L}$ in Balambu, Katunje and upstream of the Godavari Khola. The average DO values of the study area are $2.19 \mathrm{mg} / \mathrm{L}$ and $2.38 \mathrm{mg} / \mathrm{L}$ in dry season and in wet season, respectively (Annex Table 1). Inorganic reductants such as hydrogen sulphide, ammonia, nitrate and ferrous ions tend to decrease oxygen in water. Microbiological activities also consume oxygen creating the reduction of DO in water. Photosynthesis also influences the amount of DO in shallow aquifer.

Temperature is integral part to determine water quality. Various factors like sunlight, atmosphere, turbidity, mixing from other sources affect the temperature of shallow water. The temperature value ranges from 15.3 to $25.5^{\circ} \mathrm{C}$ in dry season and it seems to increase in wet season from 19.6 to $27.3^{\circ} \mathrm{C}$ showing same trend of distribution. Temperature value of the wells water are distributed heterogeneously in the study area. These suggest that the groundwater temperature is generally ambient and good for consumers who prefer cool to warm water and for the specific reason of water quality; since, bears negative impact on water quality by enhancing the growth of micro-organisms which may increase taste, odour, colour and corrosion problems (UNICEF, 2008). Therefore, it is important that groundwater temperature is not too high in order not to have microbial proliferation. Temperature affects biological, chemical and physical activities in the water (Yilmaz and Koc, 2014). Besides, increase in temperature of water decreases solubility of gases such as $\mathrm{O}_{2}, \mathrm{CO}_{2}, \mathrm{~N}_{2}$ and $\mathrm{CH}_{4}$ (Yilmaz and Koc, 2014).

The WQI map prepared in GIS from the physical data of well water shows good categories of water in some part of Balambu, Central Zoo and almost all wells of upstream of rivers except the Hanumante Khola and the Thaiba Area while average in downstream of all rivers with poor category of water in some area like Kalanki and Satdobato in dry season (Annex Table 1; Figs. 2 and 3). Same pattern is observed in the wet season with minor changes in poor water only in Kalanki area, and Satdobato well waters change to average from poor water quality.

\section{CONCLUSIONS}

Temperature, $\mathrm{pH}, \mathrm{EC}$, and $\mathrm{DO}$ of groundwater of dug wells of the southern part of the Kathmandu Valley area were studied. Temperature values can be considered as being ambient relative to the geographical region and not too bad in terms of supporting microbial growth. Average $\mathrm{pH}$ is slightly basic with wells in some areas like the Hanumante Khola, and the north western part are acidic in nature indicating corrosion problems. Electrical conductivity values are average, hence from the EC values, the groundwater of this study area can be said to have average salt concentration and good for domestic and crop production but for drinking, other factors like chemical and biological parametersof the groundwater will have to be studied. DO values, further give mixed result to the freshness of the water, implying yet again low to high organic presence. Most of parameters with few exceptions clearly fell below WHO international best standards for water quality and NDWQS. The WQI maps prepared for two seasons show little variation of physical water quality parameters. Therefore, from results of this study, the groundwater in the study area can be regarded as being of good quality for household purpose and agriculture purposes with reference to the parameters under consideration, although requiring little treatment of $\mathrm{pH}$ especially in the Nakhu Khola, EC in some wells of the Kalanki Area, and DO in the upstream part of almost all the river area. However, further studies with reference to the chemical and microbial analyses will have to be done to have a broader picture of this water quality. 
B. Bohara/ Bulletin of the Department of Geology, vol. 19, 2016, pp. 45-56

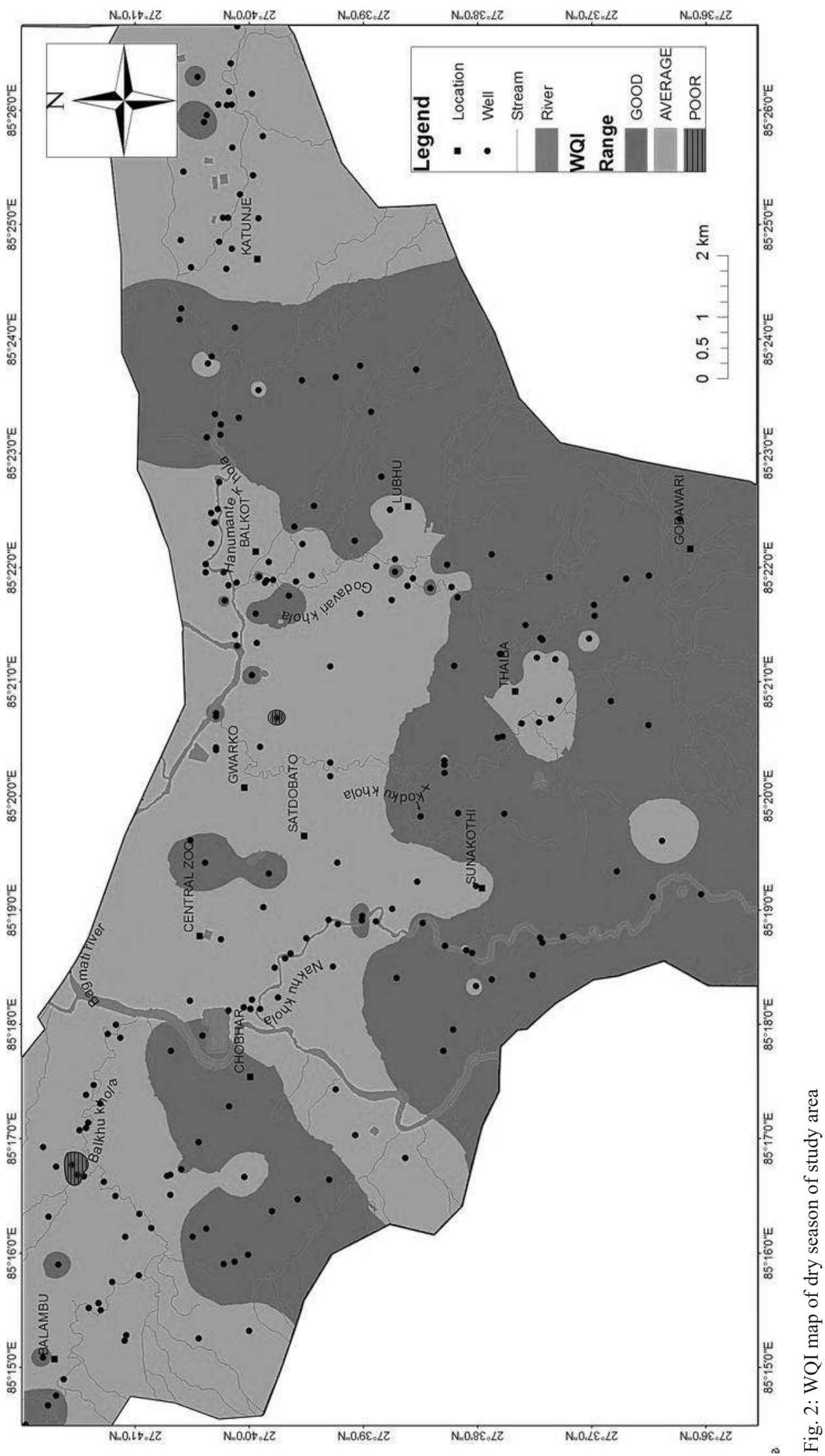




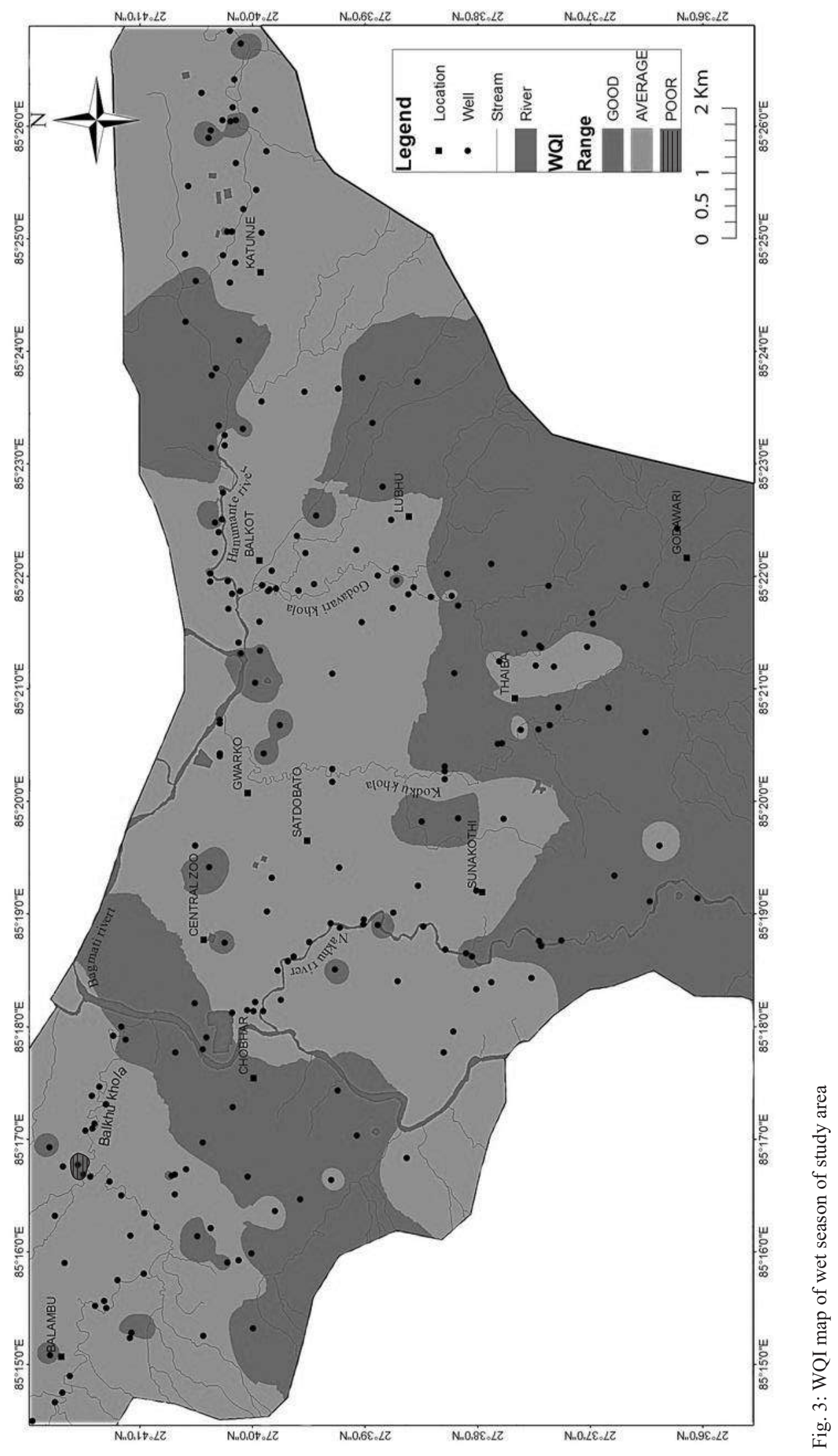




\section{ACKNOWLEDGEMENTS}

Author is grateful to thesis supervisor Dr. N. K. Tamrakar for incredible guidance. Author thanks R. Bajracharya and M. Shrestha for field assistance. Author is thankful to Central Department of Geology for providing necessary equipments and facilities.

\section{REFERENCES}

Edmunds, W.M. and Smedley P.L., 1996. Environmental Geochemistry and Health An Overview. In appleton, Fuge and McCall, (Ed.), Environmental Geochemistry and Health, Geological Society Special Publication, London, vol. 113, pp. 91-105.

Groundwater Foundation, 2012.What is groundwater? Groundwater Foundation, USA.

Gupta, I. and Kumar, A., 2015. Detection and mapping of water quality variation in Godavari River using WQI, Clustering and GIS. Journal of Geographic information system, v. 7, pp. 71-84.

Hagen, T., 1969. Report on Geological Survey of Nepal. Preliminary Reconnaissance: Denkschrifen der Schweizerischen Gessellschaft, Memories de la Sociatte Helvetique des Sciences nature, Zurich. v. 86, 185 p.

MacDonald, A. M. and Calow R. C., 2009. Developing groundwater for secure rural water supplies in Africa. Desalination. pp. 546-556.

National Drinking Water Quality Standards (NDWQS), 2005. Implementation directives for drinking water quality standards 2005. Government of Nepal, Ministry of Physical Planning and Works, Singhadarbar, Kathmandu. 20p.

Sakai, H., 2001. Stratigraphic Division and Sedimentary Facies of the Kathmandu Basin Group, Central Nepal. Journal of Nepal Geological Soc., 2001, v. 25 (special issue), pp. 19-32.

UNEP/GEMS, 2007. Water quality outlook. United Nations Environmental Programme (UNEP)/Global Environmental Monitoring System (GEMS), Burlington, Ontario, Canada.

United Nations Children's Fund, 2008. UNICEF Handbook on Water Quality. United Nations Children's Fund (UNICEF), New York, USA, 179p.

WHO, 2010. Guideline for Drinking Water Quality. World Health Organization, Geneva, Switzerland. 3rd edition.

Yilmaz, E. and Koc, C., 2014. Physically and chemically evaluation for the water quality criteria in a farm on Akcay. Journal of water resource and Protection, part 6, pp. 63-67. doi:10.4236/jwarp.2014.62010

Yoshida, M., and Gautam P., 1988. Magnetostratigraphy of Plio-Pleistocene Lacustrine Deposits in the Kathmandu Valley, Central Nepal. Proc. Indian National Science Academy, v. 54, A3, pp. 410-417.

Yoshida, M., and Igarashi, Y., 1984. Neogene to Quaternary Lacustrine Sediments in the Kathmandu Valley, Nepal. Journal of Nepal Geological Society, v. 4, pp. 73-100. 
ANNEX

Annex Table 1: Physical parameters and WQI data of dry and wet seasons

\begin{tabular}{|c|c|c|c|c|c|c|c|c|c|c|c|c|c|}
\hline \multirow[b]{2}{*}{ S. N. } & \multirow[b]{2}{*}{$\begin{array}{l}\text { Well } \\
\text { No. }\end{array}$} & \multicolumn{6}{|c|}{ Dry Season Data } & \multicolumn{6}{|c|}{ Wet Season Data } \\
\hline & & $\begin{array}{c}\mathrm{EC} \\
(\mu \mathrm{S} / \mathrm{cm})\end{array}$ & $\mathrm{pH}$ & $\begin{array}{c}\mathrm{DO} \\
(\mathrm{mg} / \mathrm{L})\end{array}$ & $\begin{array}{l}\text { Temp. } \\
\left({ }^{0} \mathrm{C}\right)\end{array}$ & WQI & Description & $\begin{array}{c}\mathrm{EC} \\
(\mu \mathrm{S} / \mathrm{cm})\end{array}$ & $\mathrm{pH}$ & $\begin{array}{c}\mathrm{DO} \\
(\mathrm{mg} / \mathrm{L})\end{array}$ & $\begin{array}{l}\text { Temp. } \\
\left({ }^{0} \mathrm{C}\right)\end{array}$ & WQI & Description \\
\hline 1 & HW1 & 1382 & 7.16 & 1.54 & 19.1 & 91 & Average & 623 & 7.61 & 3.29 & 22.8 & 63 & Good \\
\hline 2 & HW2 & 1059 & 6.95 & 0.55 & 20.1 & 87 & Average & 1221 & 7.36 & 0.98 & 22.4 & 91 & Average \\
\hline 3 & HW3 & 1142 & 6.8 & 3.31 & 19.2 & 71 & Good & 769 & 6.73 & 3 & 21.0 & 76 & Average \\
\hline 4 & HW4 & 576 & 7.56 & 1.13 & 18.6 & 76 & Average & 551 & 6.83 & 2.97 & 22.2 & 72 & Good \\
\hline 5 & HW5 & 1023 & 6.97 & 1.81 & 20.2 & 83 & Average & 1671 & 7.42 & 3 & 23.7 & 96 & Average \\
\hline 6 & HW6 & 982 & 6.65 & 0.97 & 20.1 & 85 & Average & 889 & 7.25 & 4.1 & 22.6 & 69 & Good \\
\hline 7 & HW7 & 1217 & 5.67 & 0.7 & 19.7 & 97 & Average & 1334 & 5.92 & 0.59 & 23.8 & 99 & Average \\
\hline 8 & HW8 & 604 & 6.95 & 2.31 & 19.6 & 73 & Good & 935 & 7.3 & 2.13 & 23.3 & 83 & Average \\
\hline 9 & HW9 & 746 & 7.2 & 2.13 & 19.4 & 77 & Average & 252 & 7.85 & 4.88 & 24.5 & 62 & Good \\
\hline 10 & HW10 & 571 & 6.75 & 1.05 & 20.7 & 77 & Average & 627 & 6.96 & 0.55 & 20.7 & 79 & Average \\
\hline 11 & HW11 & 852 & 7.26 & 1.94 & 18.8 & 79 & Average & 591 & 7.52 & 2.45 & 22.7 & 75 & Average \\
\hline 12 & HW12 & 1023 & 6.89 & 4.67 & 18.9 & 71 & Good & 745 & 6.94 & 3.83 & 22.2 & 65 & Good \\
\hline 13 & HW13 & 549 & 7.03 & 2.21 & 19.4 & 72 & Good & 915 & 7.34 & 1.05 & 22.5 & 85 & Average \\
\hline 14 & HW14 & 609 & 6.72 & 1.57 & 19.5 & 76 & Average & 520 & 7.06 & 2.56 & 22.8 & 73 & Good \\
\hline 15 & HW15 & 670 & 7.37 & 1.25 & 19.6 & 78 & Average & 662 & 7.2 & 2.93 & 22.3 & 74 & Good \\
\hline 16 & HW16 & 553 & 7.03 & 1.79 & 19.6 & 74 & Good & 801 & 7.22 & 3.16 & 24.2 & 66 & Good \\
\hline 17 & HW17 & 630 & 6.77 & 2.56 & 20.0 & 74 & Good & 1006 & 7.33 & 3.79 & 23.8 & 72 & Good \\
\hline 18 & HW18 & 812 & 6.96 & 3.61 & 19.2 & 65 & Good & 849 & 6.73 & 3.88 & 22.9 & 68 & Good \\
\hline 19 & HW19 & 661 & 6.65 & 1.26 & 18.9 & 77 & Average & 681 & 7.16 & 2.38 & 22.0 & 76 & Average \\
\hline 20 & HW20 & 627 & 6.76 & 0.67 & 18.4 & 78 & Average & 613 & 7.14 & 3.17 & 23.1 & 62 & Good \\
\hline 21 & HW21 & 921 & 6.61 & 2.56 & 18.8 & 79 & Average & 2158 & 7.61 & 1.32 & 24.7 & 111 & Poor \\
\hline 22 & HW22 & 855 & 6.85 & 1.12 & 18.1 & 81 & Average & 1736 & 6.98 & 1.78 & 22.1 & 99 & Average \\
\hline 23 & HW23 & 1512 & 6.9 & 1.91 & 19.0 & 92 & Average & 699 & 7.84 & 1.28 & 23.5 & 83 & Average \\
\hline 24 & HW24 & 1468 & 7.17 & 1.75 & 18.3 & 91 & Average & 784 & 7.22 & 1.14 & 23.6 & 82 & Average \\
\hline 25 & HW25 & 1160 & 7.05 & 0.55 & 19.9 & 89 & Average & 228 & 7.61 & 1.98 & 23.8 & 70 & Good \\
\hline 26 & HW26 & 1546 & 6.95 & 0.54 & 19.3 & 96 & Average & 481 & 7.7 & 3.72 & 23.5 & 62 & Good \\
\hline 27 & HW27 & 571 & 7.69 & 1.08 & 19.5 & 78 & Average & 934 & 8.05 & 1.54 & 20.7 & 87 & Average \\
\hline 28 & HW28 & 804 & 7.61 & 0.68 & 18.9 & 83 & Average & 839 & 7.03 & 2.05 & 22.3 & 80 & Average \\
\hline 29 & HW29 & 824 & 6.88 & 1.85 & 19.8 & 79 & Average & 620 & 7.51 & 3.88 & 22.2 & 64 & Good \\
\hline 30 & HW30 & 816 & 7.12 & 2.5 & 20.4 & 78 & Average & 401 & 7.34 & 2.88 & 25.3 & 71 & Good \\
\hline 31 & HW31 & 374 & 7.01 & 1.53 & 19.3 & 71 & Good & 663 & 7.27 & 2.73 & 22.3 & 75 & Average \\
\hline 32 & HW32 & 713 & 6.79 & 1.04 & 18.0 & 78 & Average & 861 & 7.57 & 0.5 & 24.6 & 87 & Average \\
\hline 33 & HW33 & 838 & 7.16 & 1.32 & 21.0 & 81 & Average & 828 & 7.52 & 1.03 & 20.7 & 83 & Average \\
\hline 34 & HW34 & 813 & 7.32 & 1.03 & 20.3 & 81 & Average & 1481 & 7.34 & 2.5 & 23.8 & 93 & Average \\
\hline 35 & HW35 & 915 & 7.07 & 0.4 & 19.6 & 84 & Average & 866 & 7.51 & 1.05 & 24.1 & 85 & Average \\
\hline 36 & HW36 & 666 & 7.37 & 0.47 & 19.3 & 80 & Average & 857 & 7.27 & 1.72 & 23.1 & 82 & Average \\
\hline 37 & HW37 & 1206 & 7.13 & 0.33 & 19.3 & 90 & Average & 1682 & 7.35 & 3.33 & 21.6 & 83 & Average \\
\hline 38 & HW38 & 1806 & 7.25 & 3.72 & 19.9 & 85 & Average & 565 & 8.13 & 6.24 & 19.9 & 72 & Good \\
\hline 39 & HW39 & 770 & 7.27 & 3.58 & 19.4 & 64 & Good & 1120 & 7.67 & 4.87 & 19.6 & 76 & Average \\
\hline 40 & HW40 & 1210 & 7.3 & 3.44 & 18.8 & 72 & Good & 1011 & 7.72 & 4.89 & 19.8 & 74 & Good \\
\hline 41 & HW41 & 778 & 7.22 & 3.53 & 19.9 & 64 & Good & 952 & 7.7 & 2.34 & 23.3 & 84 & Average \\
\hline 42 & HW42 & 1373 & 7.18 & 2.58 & 19.4 & 88 & Average & 718 & 7.15 & 1.45 & 23.9 & 80 & Average \\
\hline 43 & HW43 & 724 & 6.75 & 0.78 & 22.1 & 81 & Average & 555 & 7.26 & 6.18 & 20.8 & 67 & Good \\
\hline 44 & HW44 & 505 & 7.09 & 2.25 & 19.5 & 71 & Good & 1056 & 7.33 & 4.27 & 22.8 & 73 & Good \\
\hline 45 & HW45 & 1144 & 7.55 & 6.25 & 19.6 & 79 & Average & 1884 & 7.67 & 4.8 & 23.7 & 93 & Average \\
\hline 46 & HW46 & 340 & 7.33 & 2.37 & 19.6 & 68 & Good & 437 & 7.52 & 1.49 & 22.8 & 75 & Average \\
\hline 47 & HW47 & 397 & 7.07 & 0.74 & 18.7 & 73 & Good & 1569 & 7.31 & 2.26 & 23.6 & 95 & Average \\
\hline 48 & HW48 & 962 & 7.14 & 3.79 & 18.7 & 68 & Good & 514 & 7.4 & 0.82 & 26.4 & 79 & Average \\
\hline 49 & HW49 & 669 & 6.84 & 1.71 & 19.8 & 76 & Average & 540 & 6.8 & 1.69 & 20.5 & 74 & Good \\
\hline 50 & HW50 & 332 & 6.63 & 1.38 & 18.9 & 70 & Good & 674 & 7.1 & 2.58 & 22.4 & 75 & Average \\
\hline 51 & HW51 & 627 & 6.84 & 3.26 & 19.9 & 60 & Good & 612 & 7.14 & 2.68 & 24.7 & 75 & Average \\
\hline 52 & NW1 & 608 & 7.05 & 3 & 20.3 & 72 & Good & 666 & 6.92 & 1.03 & 21.6 & 79 & Average \\
\hline 53 & NW2 & 629 & 6.8 & 1.35 & 18.7 & 76 & Average & 940 & 7.4 & 2.52 & 23.5 & 82 & Average \\
\hline
\end{tabular}




\begin{tabular}{|c|c|c|c|c|c|c|c|c|c|c|c|c|c|}
\hline 54 & NW3 & 978 & 7.16 & 1.63 & 20.2 & 83 & Average & 867 & 7.35 & 1.92 & 21.8 & 81 & Average \\
\hline 55 & NW4 & 856 & 7.24 & 1.04 & 18.4 & 81 & Average & 856 & 7.21 & 1.91 & 22.6 & 81 & Average \\
\hline 56 & NW5 & 745 & 7.03 & 2 & 19 & 77 & Average & 937 & 7.94 & 2.51 & 24.6 & 85 & Average \\
\hline 57 & NW6 & 1058 & 6.92 & 1.34 & 20.3 & 85 & Average & 870 & 7.02 & 1.03 & 24.9 & 85 & Average \\
\hline 58 & NW7 & 1068 & 7.33 & 1.21 & 19.4 & 86 & Average & 895 & 7.53 & 2.34 & 24 & 82 & Average \\
\hline 59 & NW8 & 1131 & 7.26 & 1.71 & 19.2 & 85 & Average & 1540 & 7.72 & 2.9 & 23 & 94 & Average \\
\hline 60 & NW9 & 950 & 7.28 & 0.68 & 20.6 & 85 & Average & 501 & 7.4 & 1.39 & 24.1 & 76 & Average \\
\hline 61 & NW10 & 635 & 6.99 & 1.84 & 20.4 & 76 & Average & 938 & 7.46 & 1.19 & 22.5 & 85 & Average \\
\hline 62 & NW11 & 320 & 7.81 & 4.6 & 19.8 & 60 & Good & 827 & 7.25 & 3.57 & 24.1 & 67 & Good \\
\hline 63 & NW12 & 1052 & 7.03 & 1.26 & 18.9 & 85 & Average & 443 & 7.02 & 1 & 23.7 & 75 & Average \\
\hline 64 & NW13 & 464 & 7.04 & 0.6 & 19 & 75 & Average & 472 & 7.51 & 1.23 & 24.4 & 77 & Average \\
\hline 65 & NW14 & 458 & 7.34 & 0.8 & 19.3 & 74 & Good & 373 & 7.41 & 1.01 & 24.3 & 75 & Average \\
\hline 66 & NW15 & 401 & 7.46 & 1.09 & 20.2 & 73 & Good & 299 & 7.46 & 0.19 & 22.5 & 75 & Average \\
\hline 67 & NW16 & 452 & 7.45 & 0.5 & 19.8 & 76 & Average & 300 & 7.12 & 1.11 & 22.6 & 72 & Good \\
\hline 68 & NW17 & 345 & 7.14 & 0.55 & 19.2 & 72 & Good & 244 & 6.96 & 1.61 & 21.6 & 69 & Good \\
\hline 69 & NW18 & 264 & 6.99 & 2.79 & 19.5 & 65 & Good & 300 & 7.35 & 4.31 & 23.1 & 59 & Good \\
\hline 70 & NW19 & 370 & 7.39 & 4.2 & 18.2 & 57 & Good & 340 & 7.09 & 3.2 & 23.4 & 56 & Good \\
\hline 71 & NW20 & 396 & 7.73 & 3.45 & 19.1 & 58 & Good & 303 & 7.52 & 2.74 & 23.1 & 69 & Good \\
\hline 72 & NW21 & 242 & 7.09 & 5.7 & 20.9 & 59 & Good & 286 & 7.62 & 2.15 & 25.1 & 72 & Good \\
\hline 73 & NW22 & 371 & 7.37 & 2.76 & 19.7 & 68 & Good & 291 & 7.4 & 5.05 & 23.4 & 60 & Good \\
\hline 74 & NW23 & 335 & 7.26 & 5.4 & 18.7 & 60 & Good & 1186 & 6.18 & 2.05 & 21.1 & 89 & Average \\
\hline 75 & NW24 & 979 & 6.05 & 3.19 & 20.2 & 71 & Good & 704 & 6.8 & 5.34 & 20.4 & 68 & Good \\
\hline 76 & NW25 & 659 & 6.47 & 5.51 & 20.8 & 68 & Good & 698 & 6.6 & 2.15 & 20.3 & 77 & Average \\
\hline 77 & NW26 & 629 & 6.57 & 2.53 & 21.1 & 75 & Average & 1202 & 7.17 & 3.02 & 23.1 & 73 & Good \\
\hline 78 & NW27 & 1122 & 6.91 & 1.53 & 20.4 & 86 & Average & 1167 & 7.56 & 5.23 & 22.1 & 78 & Average \\
\hline 79 & NW28 & 1305 & 7.26 & 2.9 & 20.7 & 87 & Average & 520 & 7.67 & 5.75 & 19.9 & 66 & Good \\
\hline 80 & NW29 & 1083 & 6.67 & 4.04 & 18.3 & 71 & Good & 1028 & 6.39 & 1.6 & 22.2 & 86 & Average \\
\hline 81 & NW30 & 625 & 6.84 & 1.52 & 19.1 & 76 & Average & 951 & 6.53 & 1.8 & 22.5 & 84 & Average \\
\hline 82 & NW31 & 1025 & 6.97 & 1.4 & 20.6 & 85 & Average & 1132 & 6.72 & 0.8 & 23 & 90 & Average \\
\hline 83 & NW32 & 1035 & 6.49 & 0.5 & 17.8 & 87 & Average & 1238 & 6.88 & 1.2 & 22 & 90 & Average \\
\hline 84 & NW33 & 812 & 6.85 & 2.32 & 19.6 & 78 & Average & 916 & 6.48 & 0.5 & 22.8 & 87 & Average \\
\hline 85 & NW34 & 1257 & 7.38 & 3.54 & 19.9 & 74 & Good & 827 & 6.75 & 7.9 & 23.5 & 78 & Average \\
\hline 86 & NW35 & 720 & 6.78 & 4.04 & 19 & 64 & Good & 556 & 6.58 & 0.7 & 25.3 & 80 & Average \\
\hline 87 & NW36 & 574 & 7.69 & 7.36 & 18.2 & 71 & Good & 1091 & 7.15 & 2.3 & 22.2 & 84 & Average \\
\hline 88 & NW37 & 1071 & 7.07 & 3.35 & 18.2 & 69 & Good & 332 & 6.11 & 0.4 & 25.2 & 79 & Average \\
\hline 89 & NW38 & 511 & 6.24 & 0.55 & 19 & 78 & Average & 498 & 6.41 & 1.3 & 23.7 & 77 & Average \\
\hline 90 & NW39 & 479 & 6.66 & 5.15 & 18 & 62 & Good & 209 & 6.63 & 1.1 & 22 & 70 & Good \\
\hline 91 & NW40 & 484 & 8.07 & 0.55 & 18.9 & 79 & Average & 566 & 6.61 & 0.9 & 24.7 & 79 & Average \\
\hline 92 & NW41 & 581 & 6.46 & 0.3 & 24.2 & 81 & Average & 996 & 6.56 & 2 & 22 & 84 & Average \\
\hline 93 & NW42 & 743 & 6.64 & 0.56 & 21 & 82 & Average & 731 & 6.45 & 1.8 & 20.8 & 79 & Average \\
\hline 94 & NW43 & 865 & 6.6 & 1.42 & 18.4 & 81 & Average & 327 & 7.21 & 5.3 & 24.7 & 62 & Good \\
\hline 95 & NW44 & 297 & 7.32 & 6.33 & 21.4 & 63 & Good & 905 & 7.81 & 4 & 25.3 & 73 & Good \\
\hline 96 & NW45 & 1169 & 6.72 & 0.95 & 20.7 & 89 & Average & 874 & 6.96 & 6.7 & 21.3 & 75 & Average \\
\hline 97 & BW1 & 992 & 7.33 & 1.78 & 19.5 & 83 & Average & 859 & 7.83 & 3.64 & 23.3 & 70 & Good \\
\hline 98 & BW2 & 1694 & 7.07 & 3.03 & 18.7 & 81 & Average & 942 & 7.2 & 1.3 & 23.7 & 85 & Average \\
\hline 99 & BW4 & 896 & 7.2 & 2.17 & 20.3 & 80 & Average & 1184 & 7.09 & 1.36 & 22.8 & 89 & Average \\
\hline 100 & BW5 & 553 & 7.54 & 1.56 & 20.6 & 76 & Average & 886 & 7.4 & 1.22 & 23.9 & 84 & Average \\
\hline 101 & BW6 & 1544 & 6.95 & 3.46 & 19.8 & 79 & Average & 1335 & 6.8 & 2 & 21.7 & 90 & Average \\
\hline 102 & BW7 & 1174 & 6.78 & 1.7 & 20 & 87 & Average & 837 & 7.09 & 2 & 23.8 & 81 & Average \\
\hline 103 & BW8 & 1401 & 6.66 & 1.3 & 18.6 & 92 & Average & 785 & 6.82 & 2.8 & 24.9 & 79 & Average \\
\hline 104 & BW9 & 2860 & 7.03 & 0.37 & 20.3 & 124 & Poor & 3030 & 7.35 & 1.95 & 23.3 & 125 & Poor \\
\hline 105 & BW10 & 2140 & 6.63 & 0.38 & 19.6 & 109 & Poor & 2040 & 6.91 & 1.3 & 23.9 & 107 & Poor \\
\hline 106 & BW11 & 1661 & 6.63 & 1.04 & 19.8 & 98 & Average & 859 & 6.9 & 0.8 & 24.2 & 85 & Average \\
\hline 107 & BW12 & 583 & 6.68 & 0.5 & 19.9 & 78 & Average & 579 & 7.41 & 2.94 & 25.2 & 75 & Average \\
\hline 108 & BW13 & 797 & 6.68 & 0.7 & 19.9 & 82 & Average & 685 & 6.73 & 0.9 & 23.5 & 81 & Average \\
\hline 109 & BW14 & 689 & 7.38 & 1.28 & 18.5 & 78 & Average & 589 & 7.31 & 0.33 & 24 & 81 & Average \\
\hline
\end{tabular}




\begin{tabular}{|c|c|c|c|c|c|c|c|c|c|c|c|c|c|}
\hline 110 & BW15 & 1145 & 7.11 & 0.11 & 18.4 & 89 & Average & 865 & 7.51 & 0.69 & 24 & 86 & Average \\
\hline 111 & BW16 & 714 & 7.47 & 0.47 & 18.4 & 80 & Average & 523 & 7.53 & 0.98 & 24.3 & 78 & Average \\
\hline 112 & BW17 & 1127 & 6.98 & 1.97 & 20.1 & 85 & Average & 385 & 8.3 & 2.74 & 24.5 & 77 & Average \\
\hline 113 & BW18 & 577 & 7.14 & 0.59 & 20.6 & 78 & Average & 622 & 7.1 & 1.83 & 23 & 77 & Average \\
\hline 114 & BW19 & 1005 & 7.46 & 2.63 & 18.9 & 81 & Average & 814 & 8.04 & 2.34 & 23.5 & 84 & Average \\
\hline 115 & BW20 & 1071 & 7.39 & 0.47 & 18.6 & 87 & Average & 531 & 8.05 & 1.66 & 22.3 & 79 & Averag \\
\hline 116 & BW21 & 781 & 7.03 & 1.14 & 19.1 & 80 & Average & 635 & 7.66 & 0.43 & 22.6 & 82 & Average \\
\hline 117 & BW22 & 661 & 7.33 & 2.55 & 19 & 74 & Good & 603 & 7.81 & 1.67 & 23.5 & 79 & Average \\
\hline 118 & BW23 & 661 & 7.37 & 2.97 & 19.5 & 73 & Good & 568 & 7.8 & 1.9 & 24.6 & 79 & Average \\
\hline 119 & BW24 & 576 & 6.31 & 1.36 & 20.7 & 78 & Average & 521 & 6.58 & 3.9 & 24.7 & 63 & Good \\
\hline 120 & BW25 & 605 & 7.42 & 0.57 & 20.8 & 79 & Average & 697 & 7.62 & 0.36 & 23.4 & 83 & Average \\
\hline 121 & BW26 & 999 & 6.9 & 2.97 & 19.9 & 80 & Average & 661 & 7.01 & 2.22 & 24.6 & 77 & Average \\
\hline 122 & BW27 & 867 & 7.56 & 5.37 & 19.4 & 71 & Good & 938 & 7.46 & 1.74 & 23.6 & 84 & Average \\
\hline 123 & BW28 & 404 & 6.96 & 0.59 & 19.4 & 74 & Good & 533 & 7.46 & 2.87 & 23.9 & 73 & Good \\
\hline 124 & BW29 & 467 & 6.94 & 1.21 & 19.2 & 73 & Good & 453 & 7.63 & 1.35 & 27.3 & 78 & Average \\
\hline 125 & BW30 & 708 & 6.87 & 0.98 & 19.9 & 79 & Average & 774 & 6.92 & 2.6 & 24 & 78 & Average \\
\hline 126 & BW31 & 339 & 6.72 & 5.72 & 17.1 & 60 & Good & 708 & 6.6 & 2 & 21 & 78 & Average \\
\hline 127 & BW32 & 1408 & 6.7 & 1.48 & 19.5 & 92 & Average & 893 & 7.45 & 4.7 & 25.1 & 73 & Good \\
\hline 128 & BW33 & 886 & 7.26 & 1.88 & 18.3 & 80 & Average & 481 & 7.65 & 4 & 23.8 & 63 & Good \\
\hline 129 & BW34 & 521 & 7.32 & 3.23 & 21.8 & 60 & Good & 313 & 7.16 & 4.7 & 23.7 & 60 & Good \\
\hline 130 & BW35 & 935 & 6.68 & 1.07 & 17.9 & 83 & Average & 415 & 6.7 & 1.9 & 22.3 & 72 & Good \\
\hline 131 & BW36 & 618 & 6.92 & 1.55 & 17.6 & 75 & Average & 489 & 7.81 & 3.1 & 25.5 & 63 & Good \\
\hline 132 & BW37 & 602 & 7.32 & 1.25 & 17.5 & 75 & Average & 496 & 6.83 & 1.1 & 24.4 & 77 & Average \\
\hline 133 & BW38 & 365 & 6.76 & 2.65 & 19.3 & 68 & Good & 659 & 6.84 & 3.4 & 22.8 & 63 & Good \\
\hline 134 & BW39 & 444 & 7.23 & 0.35 & 18.4 & 75 & Average & 346 & 7.11 & 3.5 & 26.3 & 59 & Good \\
\hline 135 & BW40 & 934 & 7.19 & 6.29 & 19.4 & 74 & Good & 1382 & 6.74 & 0.9 & 23.3 & 95 & Average \\
\hline 136 & BW41 & 804 & 6.68 & 5.51 & 17.4 & 69 & Good & 382 & 7.35 & 2.8 & 25.2 & 71 & Good \\
\hline 137 & BW42 & 496 & 6.87 & 1.24 & 19.2 & 74 & Good & 572 & 6.88 & 4.2 & 22.7 & 63 & Good \\
\hline 138 & BW43 & 950 & 6.75 & 1.4 & 18.3 & 82 & Average & 386 & 6.97 & 1.8 & 25.2 & 73 & Good \\
\hline 139 & BW44 & 312 & 6.68 & 2.16 & 17.8 & 67 & Good & 899 & 6.95 & 2.9 & 23.3 & 80 & Average \\
\hline 140 & BW45 & 1005 & 7.26 & 2.95 & 19.2 & 80 & Average & 992 & 7.44 & 2.31 & 23.1 & 84 & Average \\
\hline 141 & BW46 & 1316 & 6.95 & 1.18 & 17.3 & 89 & Average & 1145 & 6.99 & 1.44 & 21.9 & 87 & Average \\
\hline 142 & BW47 & 1001 & 6.76 & 2.25 & 18.2 & 81 & Average & 928 & 6.76 & 3.4 & 20.2 & 67 & Good \\
\hline 143 & BW48 & 1011 & 6.55 & 4.23 & 21.1 & 72 & Good & 1135 & 7 & 3 & 24.1 & 84 & Average \\
\hline 144 & BW49 & 446 & 7.42 & 5.94 & 18.7 & 64 & Good & 554 & 7.21 & 3.95 & 22.4 & 62 & Good \\
\hline 145 & BW50 & 501 & 6.76 & 4.75 & 18.5 & 61 & Good & 456 & 6.4 & 2.1 & 22.3 & 74 & Good \\
\hline 146 & BW51 & 1152 & 7.04 & 1.06 & 20 & 88 & Average & 1075 & 6.86 & 0.8 & 23.6 & 89 & Average \\
\hline 147 & BW52 & 762 & 6.79 & 0.5 & 17.5 & 80 & Average & 284 & 6.71 & 0.8 & 21.6 & 72 & Good \\
\hline 148 & BW53 & 1221 & 6.78 & 0.87 & 18.9 & 89 & Average & 1211 & 6.9 & 1 & 23.8 & 91 & Average \\
\hline 149 & BW54 & 671 & 7.11 & 2.21 & 19.7 & 75 & Average & 214 & 7.44 & 3.8 & 26.2 & 57 & Good \\
\hline 150 & BW55 & 787 & 6.63 & 1.45 & 17.8 & 79 & Average & 914 & 6.84 & 1.9 & 23.2 & 82 & Average \\
\hline 151 & GW1 & 1222 & 7.13 & 2.47 & 19 & 85 & Average & 856 & 7.1 & 2.85 & 21.3 & 78 & Averas \\
\hline 152 & GW2 & 2090 & 7.16 & 1.7 & 20.4 & 105 & Poor & 1575 & 7.49 & 2.91 & 21.9 & 93 & Averas \\
\hline 153 & GW3 & 498 & 7.04 & 1.68 & 15.3 & 71 & Good & 599 & 6.96 & 1.34 & 24.5 & 78 & Averag \\
\hline 154 & GW4 & 810 & 7.03 & 2.5 & 17.5 & 76 & Average & 923 & 7.46 & 1.86 & 24.4 & 84 & Averas \\
\hline 155 & GW5 & 840 & 7.31 & 2.45 & 17.5 & 77 & Average & 815 & 7.49 & 1.92 & 24.2 & 82 & Averag \\
\hline 156 & GW6 & 608 & 7.17 & 0.71 & 18 & 77 & Average & 515 & 7.09 & 1.51 & 23.5 & 76 & Averas \\
\hline 157 & GW7 & 441 & 7.06 & 3.77 & 24 & 60 & Good & 779 & 7.41 & 1.33 & 21.3 & 81 & Averag \\
\hline 158 & GW8 & 620 & 7.23 & 0.62 & 17.4 & 77 & Average & 1099 & 7.2 & 1.25 & 22 & 87 & Averą \\
\hline 159 & GW9 & 1525 & 7.68 & 2.06 & 19.8 & 94 & Average & 876 & 7.32 & 0.79 & 23.6 & 85 & Averą \\
\hline 160 & GW10 & 944 & 7.22 & 0.72 & 16.9 & 83 & Average & 809 & 7.4 & 0.98 & 23.7 & 83 & Averag \\
\hline 161 & GW11 & 741 & 7.23 & 1.22 & 16.8 & 78 & Average & 848 & 7.54 & 3.03 & 25.2 & 68 & Good \\
\hline 162 & GW12 & 932 & 7.66 & 5.04 & 17 & 71 & Good & 725 & 7.64 & 2.86 & 25.6 & 79 & Averag \\
\hline 163 & GW13 & 747 & 7.41 & 1.11 & 15.3 & 78 & Average & 697 & 7.47 & 0.77 & 24.6 & 82 & Averas \\
\hline 164 & GW14 & 838 & 7.33 & 2.26 & 15.4 & 76 & Average & 405 & 7.7 & 2.13 & 25.2 & 75 & Avera \\
\hline 165 & GW15 & 512 & 7.3 & 1.3 & 17.5 & 73 & Good & 550 & 7.13 & 1.01 & 22.3 & 77 & Avera \\
\hline
\end{tabular}




\begin{tabular}{|c|c|c|c|c|c|c|c|c|c|c|c|c|c|}
\hline 166 & GW16 & 951 & 7.57 & 0.5 & 19 & 86 & Average & 331 & 7.26 & 1.74 & 22.9 & 71 & Good \\
\hline 167 & GW17 & 422 & 7.11 & 1.24 & 17.6 & 71 & Good & 325 & 6.96 & 1.27 & 23.5 & 72 & Good \\
\hline 168 & GW18 & 459 & 6.88 & 0.82 & 18 & 73 & Good & 346 & 7.72 & 1.01 & 24 & 76 & Average \\
\hline 169 & GW19 & 406 & 7.16 & 0.6 & 17.9 & 73 & Good & 405 & 7.63 & 1.53 & 24 & 75 & Average \\
\hline 170 & GW20 & 428 & 7.33 & 4.55 & 21.1 & 61 & Good & 409 & 7.6 & 2.11 & 24.5 & 74 & Good \\
\hline 171 & GW21 & 400 & 7.47 & 1.04 & 19.1 & 73 & Good & 340 & 7.8 & 2.94 & 22.5 & 70 & Good \\
\hline 172 & GW22 & 464 & 7.47 & 2.56 & 16.2 & 69 & Good & 322 & 7.27 & 1.81 & 23.6 & 71 & Good \\
\hline 173 & GW23 & 418 & 7.14 & 3.62 & 17.2 & 56 & Good & 350 & 7.53 & 2.97 & 23.2 & 69 & Good \\
\hline 174 & GW24 & 369 & 7.48 & 3.97 & 19.7 & 58 & Good & 362 & 7.43 & 1.24 & 23.4 & 74 & Good \\
\hline 175 & GW25 & 398 & 7.22 & 5.78 & 16.5 & 61 & Good & 299 & 7.67 & 5.21 & 19.6 & 60 & Good \\
\hline 176 & GW26 & 303 & 7.03 & 4.51 & 19.6 & 57 & Good & 776 & 7.85 & 3 & 23.6 & 80 & Average \\
\hline 177 & GW27 & 1675 & 7.09 & 1.45 & 19.9 & 97 & Average & 972 & 7.66 & 1.36 & 24.1 & 87 & Average \\
\hline 178 & GW28 & 1197 & 7.07 & 0.77 & 21.2 & 90 & Average & 474 & 7.5 & 4.1 & 22.7 & 62 & Good \\
\hline 179 & GW29 & 400 & 7.48 & 2.58 & 20.2 & 70 & Good & 752 & 7.38 & 3.13 & 20.3 & 63 & Good \\
\hline 180 & GW30 & 471 & 7.46 & 6.36 & 19.5 & 66 & Good & 591 & 7.85 & 3.68 & 22.7 & 65 & Good \\
\hline 181 & GW31 & 526 & 7.63 & 2.78 & 20.6 & 73 & Good & 440 & 7.56 & 3.41 & 25.3 & 61 & Good \\
\hline 182 & GW32 & 359 & 7.24 & 5.55 & 19.5 & 61 & Good & 1050 & 7.22 & 2.38 & 22.6 & 84 & Average \\
\hline 183 & GW33 & 1004 & 6.95 & 2.73 & 19.3 & 80 & Average & 741 & 7.43 & 2.44 & 22.9 & 78 & Average \\
\hline 184 & GW34 & 853 & 7.14 & 2.45 & 19.9 & 78 & Average & 866 & 7.7 & 1.91 & 24.1 & 84 & Average \\
\hline 185 & GW35 & 846 & 7.18 & 2.05 & 19.6 & 79 & Average & 1382 & 7.37 & 0.97 & 24.8 & 95 & Average \\
\hline 186 & GW36 & 1268 & 7.06 & 1.3 & 19.3 & 89 & Average & 960 & 7.55 & 1.43 & 24 & 86 & Average \\
\hline 187 & GW37 & 470 & 7.16 & 2.2 & 21.5 & 72 & Good & 742 & 7.74 & 3.77 & 25.7 & 69 & Good \\
\hline 188 & GW38 & 734 & 7.2 & 3.85 & 20.1 & 64 & Good & 829 & 8.16 & 5.17 & 25.7 & 77 & Average \\
\hline 189 & GW39 & 1007 & 7.13 & 1.29 & 21.3 & 85 & Average & 425 & 6.9 & 0.96 & 24.6 & 76 & Average \\
\hline 190 & GW40 & 528 & 6.8 & 3.7 & 19.5 & 59 & Good & 685 & 7.42 & 0.22 & 24.5 & 83 & Average \\
\hline 191 & GW41 & 946 & 7.09 & 0.72 & 21.2 & 85 & Average & 344 & 7.12 & 2.18 & 23.4 & 70 & Good \\
\hline 192 & GW42 & 399 & 6.95 & 3.05 & 19.4 & 55 & Good & 590 & 7.48 & 3.12 & 24.1 & 62 & Good \\
\hline 193 & GW43 & 497 & 7.53 & 1.63 & 19 & 74 & Good & 856 & 7.9 & 5.29 & 20.9 & 74 & Good \\
\hline 194 & GW44 & 848 & 7.5 & 5.13 & 18.6 & 70 & Good & 428 & 7.31 & 2.38 & 24.1 & 72 & Good \\
\hline 195 & GW45 & 468 & 6.74 & 2.56 & 21.3 & 71 & Good & 1072 & 7.55 & 5.04 & 20 & 75 & Average \\
\hline 196 & KW1 & 1054 & 7.53 & 5.4 & 15.9 & 73 & Good & 1279 & 7.44 & 1.15 & 22.5 & 92 & Average \\
\hline 197 & KW2 & 1021 & 7.57 & 5.45 & 15.9 & 73 & Good & 1568 & 7.47 & 1.27 & 23.8 & 98 & Average \\
\hline 198 & KW3 & 1840 & 6.71 & 0.31 & 16 & 102 & Poor & 1187 & 7.59 & 1.06 & 24.8 & 92 & Average \\
\hline 199 & KW4 & 977 & 7.18 & 0.86 & 17.3 & 83 & Average & 872 & 7.33 & 1.5 & 22.5 & 83 & Average \\
\hline 200 & KW5 & 847 & 7.27 & 0.42 & 18.2 & 83 & Average & 1142 & 7.13 & 1.21 & 22.1 & 88 & Average \\
\hline 201 & KW6 & 1092 & 6.86 & 1.31 & 19.7 & 86 & Average & 945 & 7.29 & 0.42 & 23.3 & 87 & Average \\
\hline 202 & KW7 & 804 & 7.16 & 0.57 & 16.2 & 80 & Average & 371 & 8.06 & 3.63 & 24.9 & 63 & Good \\
\hline 203 & KW8 & 528 & 7.66 & 0.09 & 15.9 & 77 & Average & 516 & 6.95 & 2.83 & 24.2 & 73 & Good \\
\hline 204 & KW9 & 320 & 7.13 & 1.06 & 15.5 & 69 & Good & 1204 & 7.39 & 0.5 & 22 & 92 & Average \\
\hline 205 & KW10 & 416 & 7.03 & 0.9 & 16.8 & 72 & Good & 421 & 7.61 & 2.64 & 23.7 & 72 & Good \\
\hline 206 & KW11 & 455 & 7.07 & 0.5 & 17.8 & 74 & Good & 432 & 7.32 & 2.15 & 23.3 & 73 & Good \\
\hline 207 & KW12 & 294 & 7.03 & 1.35 & 17.2 & 68 & Good & 796 & 7.09 & 2.85 & 21 & 77 & Average \\
\hline 208 & KW13 & 999 & 6.62 & 1.43 & 18.6 & 83 & Average & 468 & 6.81 & 2.15 & 21.2 & 72 & Good \\
\hline 209 & KW14 & 568 & 7.89 & 0.82 & 17.5 & 78 & Average & 312 & 7.15 & 1.29 & 21.4 & 71 & Good \\
\hline 210 & KW15 & 570 & 7.05 & 0.47 & 17.8 & 76 & Average & 375 & 7.86 & 1.94 & 23 & 74 & Good \\
\hline 211 & KW16 & 511 & 8.03 & 9.1 & 20.8 & 77 & Average & 183 & 6.6 & 1.22 & 21.6 & 69 & Good \\
\hline 212 & KW17 & 267 & 7.2 & 2.46 & 19 & 66 & Good & 347 & 6.51 & 2 & 21.3 & 71 & Good \\
\hline 213 & KW18 & 230 & 6.16 & 3.68 & 22 & 57 & Good & 894 & 7.35 & 4.45 & 23.2 & 71 & Good \\
\hline 214 & KW19 & 1336 & 7.04 & 1.22 & 19.9 & 91 & Average & 933 & 7.56 & 4.84 & 22.7 & 73 & Good \\
\hline 215 & KW20 & 1869 & 7.11 & 0.41 & 18.5 & 103 & Poor & 1269 & 7.25 & 2.37 & 22.8 & 88 & Average \\
\hline 216 & KW21 & 1022 & 6.77 & 4.14 & 18.9 & 70 & Good & 512 & 7.29 & 5.16 & 20.2 & 63 & Good \\
\hline 217 & KW22 & 404 & 7.16 & 6.49 & 18.6 & 63 & Good & 860 & 6.44 & 4.39 & 20.1 & 69 & Good \\
\hline 218 & KW23 & 845 & 6.54 & 5.24 & 19.2 & 70 & Good & 371 & 8.06 & 3.63 & 24.9 & 63 & Good \\
\hline
\end{tabular}

